\title{
RAUIELLA THUIDIOIDES, SP. NOV. (LESKEACEAE, BRYOPHYTA), A NEW SPECIES FROM THE RUSSIAN FAR EAST
}

\section{RAUIELLA THUIDIOIDES, SP. NOV. (LESKEACEAE, BRYOPHYTA), НОВЫЙ ВИД С РОССИЙСКОГО ДАЛЬНЕГО ВОСТОКА}

\author{
JAN KUČERA ${ }^{1}$, ElENA A. IGNATOVA ${ }^{2}$, MiChAEL S. IGNATOV ${ }^{2,3}$, AlinA V. FEDOROVA ${ }^{3}$, \\ OXANA I. KUZNETSOVA ${ }^{3}$ \& VLADIMIR E. FEDOSOV ${ }^{2,4}$ \\ ЯН КУЧЕРА ${ }^{1}$, ЕЛЕНА А. ИГНАТОВА ${ }^{2}$, МИХАИЛ С. ИГНАТОВ ${ }^{2,3}$, АЛИНА В. ФЕДОРОВА ${ }^{3}$, \\ ОКСАНА И. КУЗНЕЦОВА ${ }^{3} \&$ ВЛАДИМИР Э. ФЕДОСОВ ${ }^{2,4}$
}

Abstract

\begin{abstract}
Molecular barcoding of a morphologically unfamiliar thuidiaceous moss, known so far from two specimens collected in the Sikhote-Alin mountain range suggested the affinity with the genus Rauiella. Subsequent evaluation in a broader phylogenetic context of Leskeaceae s. lat. using nuclear ribosomal ITS and chloroplast $\operatorname{trn} \mathrm{F}-\operatorname{trn} \mathrm{S}$ regions confirmed that the plants which morphologically substantially differ from known representatives of Rauiella are molecularly likewise distinctive. It is therefore described and illustrated here as a new species, Rauiella thuidioides. We further discuss the morphological differences from its congeners and other similar taxa, as well as its ecology and geographical affinities. Finally, we also touch the delimitation of the genus Rauiella and advocate the synonymy of Thuidiaceae with Leskeaceae.
\end{abstract}

Резюме

Предварительное изучение с помощью молекулярных маркеров двух образцов неизвестного вида из семейства Thuidiaceae, собранных на хребте Сихоте-Алинь в Приморском крае, показало их сходство с родом Rauiella. Последующая оценка их положения в более широком филогенетическом контексте семейства Leskeaceae s. lat. с помощью ядерного участка ITS и хлоропластного $\operatorname{trn} \mathrm{F}-\operatorname{trn} \mathrm{S}$ подтвердила их принадлежность к этому роду; при этом были показаны существенные морфологические и молекулярные отличия этих образцов от известных представителей Rauiella. Эти растения описаны и проиллюстрированы как новый вид Rauiella thuidioides. Обсуждаются его отличия от других видов Rauiella и морфологически сходных видов из других родов, а также особенности экологии и распространения нового вида. Рассмотрены также объем и границы рода Rauiella и приведены доводы в пользу синонимизации семейства Thuidiaceae c Leskeaceae.

KEYWORDS: Hypnales, molecular barcoding, ITS, trnF-trnS, cryptic diversity

\section{INTRODUCTION}

In course of identification of specimens collected in 2013 at the well-known locality of Elomovsky Klyuch valley beneath Benevskie waterfalls (Sikhote-Alin mountains, Primorsky Territory, Russian Far East), the second author (EA) was puzzled by a thuidiaceous moss, which combined the characteristics of Rauiella fujisana (Paris) Reimers (pluripapillose lamina cells) with the branching pattern unknown in this species (sparse but at least partly bipinnate branching) and pointing thus rather towards Thuidium Schimp. s.str., although such sparse branching is also unknown in the Far East Asian representatives of Thuidium with pluripapillose cells, i.e., $T$. submicropteris Cardot, T. subglaucinum Cardot, and T. kanedae Sakurai. Several years later, JK and VF visited the site again and JK happened to collect the same moss again and was puzzled in the same way when attempting at naming this collection. Molecular barcoding using the nrITS and chloroplast rps4 regions pointed towards the affinity with Rauiella fujisana, rather than with Thuidium, but only sequences of $R$. fujisana, $R$. lagoensis (Hampe) W.R. Buck, and $R$. praelonga (Schimp. ex Besch.) Wijk

\footnotetext{
1 - University of South Bohemia, Faculty of Science, Department of Botany, České Budějovice, Czech Republic; e-mail: kucera@prf.jcu.cz. ORCID (JK) 0000-0002-0230-5997

2 - Lomonosov Moscow State University, Biological Faculty, Geobotany Dept., Leninskie Gory Str. 1-12, Moscow 119991 Russia; e-mail: arctoa@list.ru. ORCID (EI) 0000-0001-6287-5660

3 - Tsitsin Main Botanical Garden, Russian Academy of Sciences, Botanicheskaya Str., 4, Moscow 127276 Russia; e-mails: misha_ignatov@list.ru; oikuznets@gmail.com; alina_77777@mail.ru. ORCID (MI) 0000-0001-6096-6315, (OK) 0000-00025513-1329, (AF) 0000-0001-7362-2124.

${ }^{4}$ - Botanical Garden-Institute, FEB RAS, Makovskogo Street, 142, Vladivostok, 690024, Russia; e-mail: fedosov_v@mail.ru. ORCID (VF) 0000-0002-5331-6346
} 
\& Margad. were publicly accessible (the latter two only for rps4, mitochondrial nad5 intron, and nuclear LSU) at that time, and the representation of the East Asian $R$. fujisana in GenBank was very scarce. We decided therefore to sample molecularly a few additional specimens of R. fujisana and add the eastern North American R. scita, which is the type of the genus but has not yet been sampled for molecular data. Published molecular phylogenetic accounts with greater emphasis on Thuidiaceae or Leskeaceae s.lat. are sparse and include a smaller account by García-Ávila et al. (2009), who used chloroplast $r b c \mathrm{~L}$ and $r p s 4-t r n \mathrm{~S}$ regions, the unpublished dissertation by Soares (2015), who used the combination of chloroplast rps4, mitochondrial nad5 intron and nuclear ribosomal LSU, the arXiv-indexed paper by Cai et al. (2019), who used the combination of nuclear ribosomal ITS with the plastid $t r n \mathrm{~L}-t r n \mathrm{~F}, r p s 4$, and $a t p \mathrm{~B}-r b c \mathrm{~L}$, and a small account published on the occasion of the description of a new thuidiaceous genus, Lazarenkoa Ignatov \& Ignatova nom. illeg. (Ignatov et al., 2019), now replaced by Ignatovia U.B. Deshmukh (Deshmukh, 2021); here the molecular dataset was based on the combination of nuclear ribosomal ITS with the plastid trnL-trnF.

The genus Rauiella was in fact described by Austin (1880) [as Rauia Aust.] to accommodate the eastern North American species which was then recognized as Thuidium scitum (P. Beauv.) Austin. He considered the 'leskeaceous' capsule form and peristome as diagnostic characters worth segregating it from Thuidium. Unfortunately, he has not noticed that the name has already been in use for a rutaceous plant described in 1823 and this failure was corrected by Reimers (1937), who coined a replacement name, Rauiella Reimers, and added the second species to the delimitation of the genus, the east Asian R. fujisa$n a$. His concept was already close to the modern one, having emphasized the monoicy, simple pinnate branching of plants, dense paraphyllia, pluripapillose cells, and erect cylindrical capsule with short operculum and 1-2 endostome cilia between teeth. Several new combinations to the genus were added by Wijk \& Margadant (1962) without a dedicated study, and the last addition to the concept of Rauiella was made by Buck (1991), who newly combined into the genus the chiefly neotropical species, $R$. lagoensis. The genus is currently rather generally accepted, based probably on the reasoning provided by both Buck \& Crum (1990) and Touw (2001), although Noguchi et al. (1991) preferred the broad delimitation of the genus Thuidium, which included Pelekium Mitt., Bryochenea C. Gao \& K.C. Chang, Abietinella Müll. Hal., and Rauiella. Rauiella has not yet been studied in broader phylogenetic context and sadly, the neotropical species, $R$. lagoensis and $R$. praelonga, which differ in several morphological aspects from the northern temperate species, $R$. scita and R. fujisana (Touw 2001), were never included together in one of the above-mentioned phylogenetic studies but doubts on the phylogenetic coherence of the groups can be deduced from the markedly different affinities of $R$. lagoensis, which appears mostly closely related to Haplocladium microphyllum (Sw. ex Hedw.) Broth. (García-Avila et al., 2009), while R. fujisana appears closest to Abietinella and Bryonoguchia (Cai et al., 2019; Ignatov et al., 2019). The acceptance of the whole family Thuidiaceae with respect to Leskeaceae appears controversial, as the Thuidiaceae comprising at least the genera accepted in the broad Thuidium concept of Noguchi et al. (1991) are firmly rooted among bryologists, but the above-mentioned phylogenetic studies strongly favour the concept of broad Leskeaceae, as adopted by Allen (2018).

\section{MATERIAL AND METHODS}

Based on the published molecular data in Leskeaceae s.lat. with respect to the phytogeographic focus of the sampling, we decided that the most logical combination of loci to use in this study would be the combination of nrITS and chloroplast $\operatorname{trn} \mathrm{F}$-trnS regions. These loci were used in the treatments by Cai et al. (2019) and Ignatov et al. (2019), although none of them employed the complete $\operatorname{trn} \mathrm{F}-\operatorname{trn} S$ region; the variability of the $\operatorname{trn} \mathrm{L}-\operatorname{trn} \mathrm{T}$ and $t r n \mathrm{~T}$ rps 4 spacer was, however, found phylogenetically informative, e.g., in the recent molecular-phylogenetic study of Orthothecium (Ignatov et al., 2020). Use of the region however enables employing accessions for which only trnL$t r n \mathrm{~F}$ or $r p s 4-t r n \mathrm{~S}$ part is available. We used the datasets published by Cai et al. (2019) and Ignatov et al. (2019) as a basis for the matrix, and supplemented it with the newly obtained sequences of Rauiella and other Leskeaceae s.lat., as specified in the Appendix.

Retrieval of sequences followed the laboratory protocols specified in Kučera et al. (2019) and Ignatov et al. (2020). Raw sequences were trimmed from primer complements, checked and corrected for reading errors and inserted into preliminary matrices based on the abovementioned phylogenetic studies, observing our later achievements, particularly the larger study by Kučera et al. (2019). ITS and chloroplast matrices were initially aligned and evaluated in phylogenetic context separately. We used the online interface of Mafft ver. 7 (https:// mafft.cbrc.jp/alignment/server/) to align our matrices using the E-INS-i aligning strategy with otherwise default options and checked the results for obvious inconsistencies manually. We employed Bayesian inference (BI) and Maximum Likelihood (ML) analysis for the phylogenetic inference. The analyses were calculated in MrBayes v. 3.2.7a (Ronquist et al., 2012) and RAxML v. 8.2.12 (Stamatakis, 2014) software packages, run at the cluster facilities of Metacentrum VO (see acknowledgement), following the algorithms specified in Kučera et al. (2019). Chloroplast and ITS matrices were not further partitioned but upon inspection of inconsistencies between the results from these partial analyses, we have not discovered discrepancies at supported nodes which would prevent us from concatenation and therefore we 
Fig. 1. Bayesian tree of the Leskeaceae s.l. inferred from the combined nuclear and plastid data. Bayesian posterior probabilities higher than 0.7 and bootstrap support values higher than 50 from ML analysis are shown at branches; hyphens indicate $\mathrm{BS}<50$ in the ML tree and absence of numbers indicates the absence of node in the ML tree. Accessions are identified by isolate numbers for newly sampled specimens, data downloaded from GenBank are identified by accession numbers.

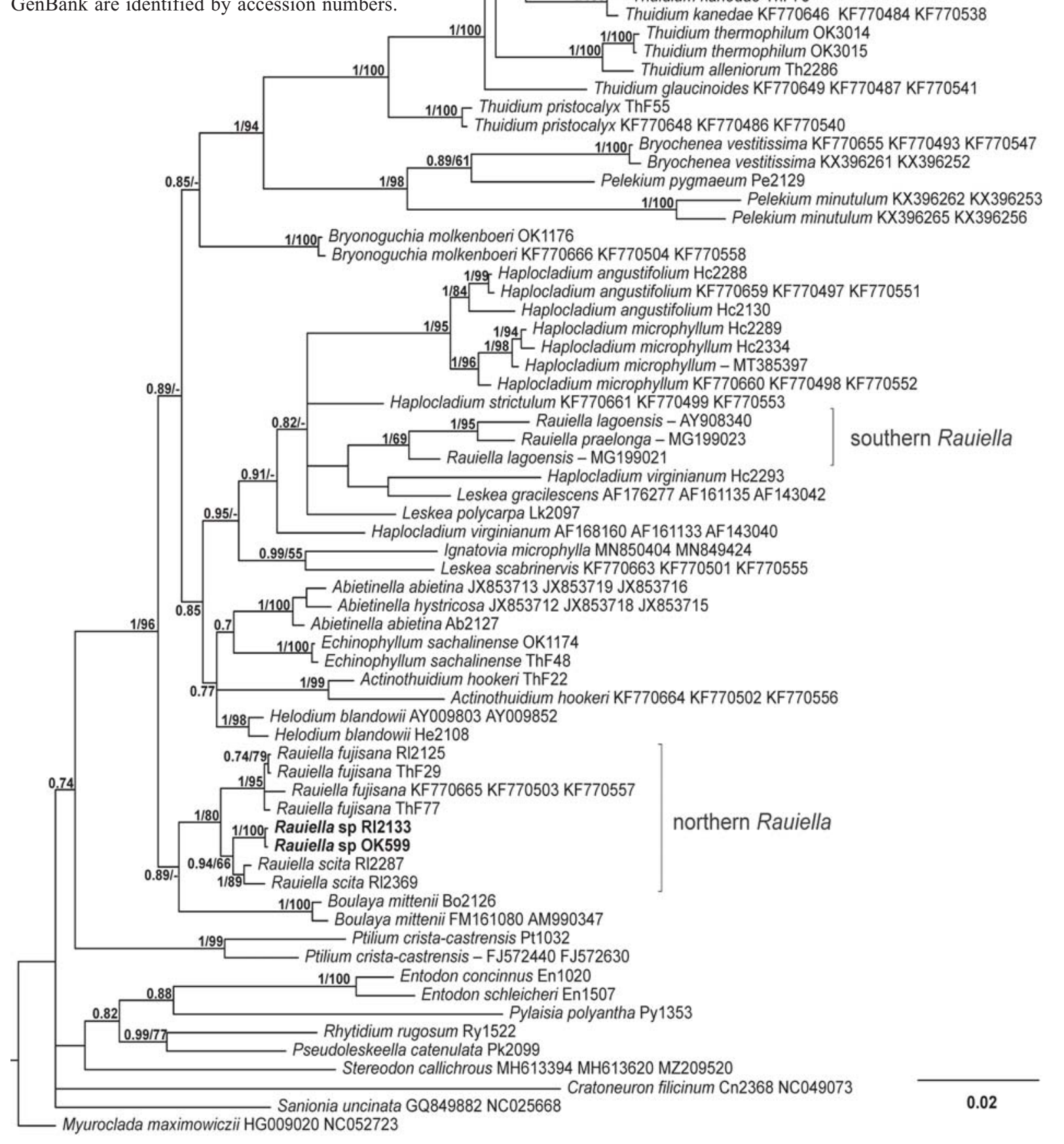

1/98 Thuidium assimile Th2100

1/98 Thuidium assimile KF770638 KF770476 KF770530

Thuidium assimile Th2135

.981- Thuidium assimile KF770643 KF770481 KF770535

$1 / 99$ Thuidium subglaucinum KF770642 KF770480 KF770534

Thuidium subglaucinum KF770645 KF770483 KF770537 $1 / 100$ Thuidium delicatulum Th2278

Thuidium delicatulum ThF57

Thuidium tamariscinum Th2197

1/100 [ Thuidium tamariscinum ThF56

1/100. Thuidium kanedae ThF54

$1 / 100$. Thuidium kanedae ThF54

idium thermophilum OK3014

Thuidium thermophilum OK3015

F770648 KF770486 KF77054

ium pygmaeum $\mathrm{Pe} 2129$

KX396253

Haplocladium angustifolium $\mathrm{Hc} 2288$

84 Haplocladium angustifolium KF770659 K

Haplocladium microphyllum $\mathrm{Hc22} 29$

KF77055

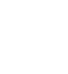


fore only the results obtained from the analysis of concatenated matrices (Fig. 1). All sampled Thuidiaceae and Leskeaceae accessions form together a well-supported monophyletic unit. The type of Leskeaceae, Leskea polycarpa, appears nested in a weakly supported lineage containing accessions of Haplocladium, Rauiella lagoensis and $R$. praelonga, and Ignatovia. Members of Thuidi$u m$, on the other hand, appear in a fully supported clade which is sister to fully supported Pelekium clade that also includes Bryochenea. The composite lineage of Thuidium and Pelekium+Bryochenea appears sister to Bryonoguchia to form a virtually unsupported clade. All other relationships at supra-generic rank are poorly supported or not supported at all. Members of Rauiella form two markedly distant lineages, the northern lineage (PP 1/ BS 80) comprising the temperate representatives $R$. sci$t a, R$. fujisana and the two accessions of plants from Elomovsky Klyuch which form a weakly supported monophylum (PP 0.94/BS 66) with the North American $R$. scita, while $R$. fujisana is sister to this lineage. The whole northern Rauiella lineage appears sister to Boulaya, comprising a very weakly supported clade (PP 0.89/BS-). The undescribed Rauiella shares rps4-trnS sequence with $R$. scita but differs in five substitutions in the remaining part of trnF-rps 4 region and five in ITS. Rauiella fujisana differs in additional 10 substitutions in trnF-rps 4 region, two substitutions in the rps4trnS region and 8 in ITS. The southern Raviella representatives appear within a poorly supported clade that includes analysed accessions of Haplocladium, Leskea and Ignatovia.

\section{DISCUSSION}

The morphologically distinct plants collected several times in the valley of Elomovsky Klyuch in the southern part of Sikhote-Alin mountain range were molecularly confirmed to be a member of the "northern Rauiella lineage", i.e., the genus Rauiella in the strict sense. The structure of molecular variability in this lineage fully supports the recognition of three identically evaluated taxa, showing little infraspecific variation and substantially larger divergence among taxa. The undescribed member of Rauiella is more closely related to the eastern North American $R$. scita than to the sympatrically occurring $R$. fujisana. At the same time, R. scita is not known to occur outside its endemic distribution range between North Carolina and Quebec, eastern Atlantic coast and Iowa in the west (Buck, 2014). The polyphyly of Rauiella, as currently delimited, calls for the re-evaluation of the genus, as already suggested by Touw (2001), who stated that the neotropical Rauiella members possess character states he considered as derived with respect to northern species, including irregular branching pattern, paraphyllia with few and short branches, weakly differentiated stem and branch leaves, muticous stem leaves, strong costae with dorsal superficial costa cells chlorophyllose, similar to adjacent lamina cells, long and sheathing perichaetial leaves and reduced peristomes. They also share the acute, sharp terminal cell of branch leaves in contrast to truncate and pluripapillose cells of the northern species (Buck, 2014). We have not had the possibility of studying the tropical representatives of the genus and the phylogenetic affinities are assessed only from the rps 4 part of the trnF-trnS region which we employed in most other cases. The comprehensive revision of Rauiella is nevertheless far beyond the scope of the current paper.

The results from our phylogenetic analysis also fully support the idea of merging the traditionally recognized family of Thuidiaceae with Leskeaceae (Allen, 2018). Should the two families be maintained, it would necessitate either segregating several new families with low support and hardly any morphological substantiation (one of them containing probably the northern Rauiella clade with Boulaya), or the acceptance of monophyletic crown group of Thuidiaceae containing probably only Thuidium and Pelekium at the cost of paraphyletic Leskeaceae represented by the grade of all basal thuidiaceous/ leskeaceous genera. Neither of these solutions seems to be more convenient than the somewhat unusual broad delimitation of Leskeaceae, where however only the genus Leskea is retained in the classical delimitation of the family (Brotherus, 1925).

\section{TAXONOMY}

Rauiella thuidioides Jan Kučera \& Ignatova, spec. nov. Fig. 2, 3A-D, 4A-D.

Holotype: Russian Federation, Primorsky Territory, Lazo Distr.: Elomovsky Klyuch valley, 43¹3'39.3"N, $133^{\circ} 45^{\prime} 47.6^{\prime \prime E}, 250 \mathrm{~m}$ a.s.l., on mossy rocks in mixed conifer-broadleaved forest, 5 September 2013, coll. Ignatov, Ignatova \& Malashkina 13-1264 (MHA9101928). Isotype MW9092266.

Paratypes: (1) Russian Federation, Primorsky Territory, Lazo Distr.: Elomovsky Klyuch valley, 43¹3'10"N, $133^{\circ} 46^{\prime} 31^{\prime \prime E}, 200 \mathrm{~m}$ a.s.1., broad-leaved alluvial wood; on half-shaded siliceous boulder, 5 September 2019, coll. J. Kučera 21299 (CBFS). (2) The same area, without exact coordinates, ca. $200 \mathrm{~m}$ a.s.l., on rocks in a mixed floodvalley forest, 6 September 2006, coll. Ignatov, Ignatova \& Cherdantseva 06-2175 (MHA9131243, MW9092267).

Etymology. The specific epithet refers to thuidioid appearance which results from the presence of sparsely bipinnate branching.

Diagnosis. The species differs from its congeners, and particularly from $R$. fujisana and $R$. scita, in its sparse branching which reveals rich paraphyllia present on stem, the occasional production of second order branches from the primary ones, and the larger stem leaves, mostly exceeding $1 \mathrm{~mm}$ in length and $0.5 \mathrm{~mm}$ in width. The differences from Thuidium species with pluripapillose cells (T. submicropteris, T. subglaucinum, T. kanedae, T. alleniorum) include autoicous gametangia and less regular and less dense, mostly unipinnate branching. Boulaya 


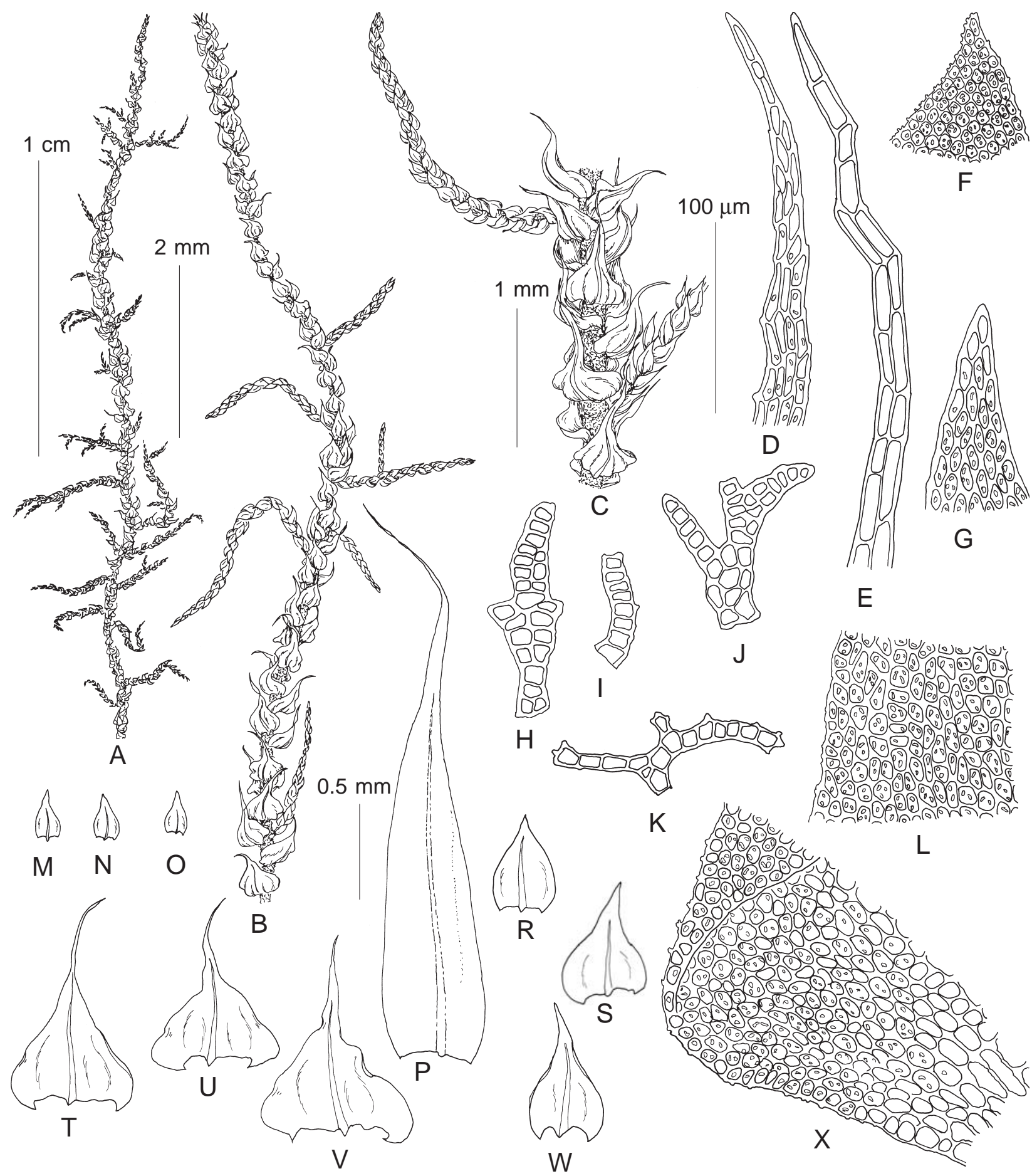

Fig. 2. Rauiella thuidioides (from holotype). A-C: habit, dry; D-E: cells of stem leaf acumina; F: cells of the apical portion of the secondary branch leaf; G: cells of the apical portion of the primary branch leaf; H-K: paraphyllia; L: median cells of stem leaf; M-O: branch leaves from secondary branches; P: inner perichaetial leaf; R-S, W: branch leaves from primary branes; T-V: stem leaves; X: basal cells of stem leaf. Scale bars: $1 \mathrm{~cm}$ for A; $2 \mathrm{~mm}$ for B; $1 \mathrm{~mm}$ for C; $0.5 \mathrm{~mm}$ for M-W; $100 \mu \mathrm{m}$ for D-L, X.

mittenii is more densely, unipinnately branched, has unipapillose cells and is dioicous.

Description: Plants in loose, interwoven mats, rigid, green or yellowish-green, dull but with glossy stem leaf apices. Stems to $8 \mathrm{~cm}$ long, $0.5-1.0 \mathrm{~mm}$ wide with leaves, sparsely and irregularly branched, often with secondary branchlets on primary branches; central strand absent; medullary cells firm-walled, cortical cells in 3-4 layers thick-walled, brown, hyalodermis absent; paraphyllia numerous on stems and primary branches, filamentose and foliose, branched. Stem leaves incurved when dry, widely spreading when moist, $0.9-1.2 \times 0.6-0.8 \mathrm{~mm}$, from wide triangular or cordate-deltoid bases abruptly narrowed into long, narrow triangular acumina, with unise- 

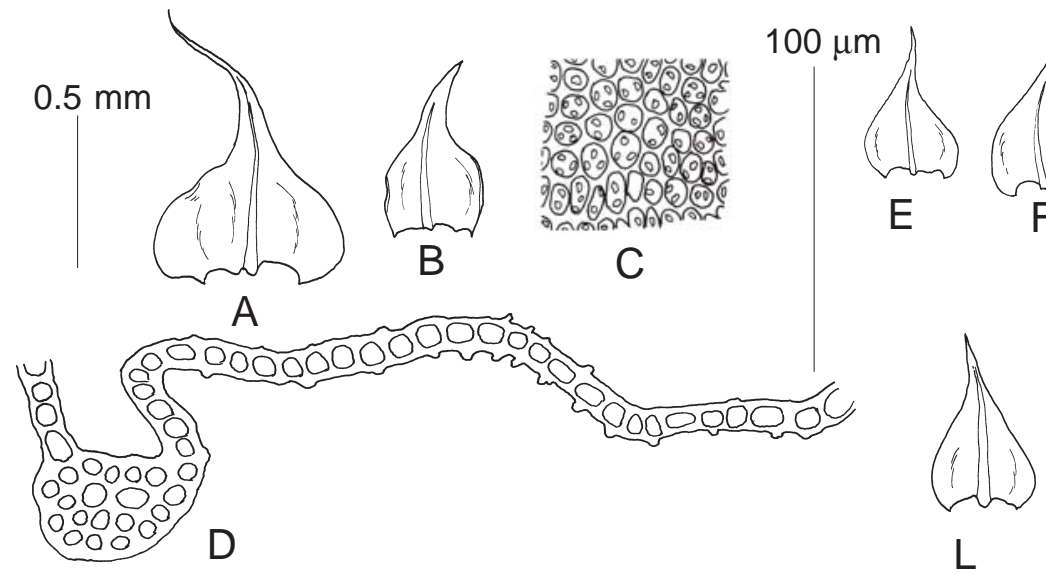

Fig. 3. A comparison of North Hemispheric Rauiella species. A-D: R. thuidioides (from holotype). E-K: R. fujisana (from: Russia, Primorsky Territory, Dalnegorsk District, Ignatov \& Ignatova 13-1601, MHA). L-S: R. scita (from: U.S.A., Maine, Allen 28294, MHA). A, E-G, L-N: stem leaves; B, H-I, O-P: branch leaves; C, J, R: median laminal cells; D, K, S: leaf transverse sections. Scale bars: $0.5 \mathrm{~mm}$ for A-B, E-I, L-P; $100 \mu \mathrm{m}$ for C-D, J-K, R-S.

riate apices $2-4$ cells long, abruptly rounded to the insertion, strongly plicate; costae extending to the base or middle part of narrow acumina, gradually tapered distally; margins entire, plane or recurved at places in basal half; median laminal cells irregularly polygonal and transversely ovate, with moderately thickened walls, slightly collenchymatous, with several round and 0 shaped, low papillae over lumina mainly on dorsal side of leaf lamina, 5-12×7-10 $\mu \mathrm{m}$; cells of acumina elongate, $25-30 \times 5-8 \mu \mathrm{m}$, smooth. Primary branch leaves with ovate base and triangular acumina, $0.55-0.70 \times 0.3-$ $0.4 \mathrm{~mm}$, apical cell sharp, smooth; secondary branch leaves ovate, $0.2-0.25 \times 0.12-0.14 \mathrm{~mm}$, apical cell truncate, papillose. Autoicous. Perichaetia on stem, conspicuous. Inner perichaetial leaves narrowly lanceolate, ca. 2.5-3.0 $\times 0.5 \mathrm{~mm}$, not plicate, with long, filiform, flexuose acumina, uniseriate apices 3-4 cells long; margins plane, serrulate throughout; costa to 0.7 the leaf length, weakly delimited from adjacent cells; laminal cells oblong, smooth. Perigonia on stem close to perichaetia, small, inconspicuous. Setae 1.8-2.2 mm long, yellowish or yellow brown. Capsules inclined, cylindrical, slightly curved, 1.8-2 mm long and 0.8-0.9 mm wide. Opercula and annuli not seen. Exostome teeth ca. $500 \mu \mathrm{m}$ long, light yellow, cross-striolate below, papillose above. Endostome with basal membrane ca. $250 \mu \mathrm{m}$ high; segments as long as exostome, narrow, not or scarcely perforated; cilia in groups of 2-3, nodose. Spores 9-11 $\mu \mathrm{m}$, very finely papillose. Calyptrae not seen.

Differentiation. Rauiella thuidioides can be rather easily differentiated from the co-occurring common East Asian $R$. fujisana by the longer, up to $8 \mathrm{~cm}$ long stems, much sparser branching with somewhat irregularly long primary branches and particularly by the sparse but rather regular appearance of short secondary branches arising from the primary ones (cf. Fig. 4C). Stem leaves are larger, $0.9-1.2 \times 0.6-0.8 \mathrm{~mm}$ vs. to $0.9 \times 0.45 \mathrm{~mm}$ (as specified by Noguchi et al., 1991), are more strongly plicate and have typically longer, piliferous apices (Fig. 3 ), although this character is rather variable in R. fujisa$n a$. Leaf laminal cells of $R$. fujisana are covered by dense, coarse, forked papillae on both leaf surfaces (Fig. $3 \mathrm{~K}$ ), while in $R$. thuidioides the papillae are smaller, less massive, simple or indistinctly bifid (0-shaped), more numerous on dorsal surface of leaf lamina (Fig. 3D). Rauiella thuidioides also differs from R. fujisana in longer setae (1.8-2.2 vs. $1.0-1.2 \mathrm{~mm})$, longer exostome teeth (500 vs. $350 \mu \mathrm{m})$, and smaller, finer papillose spores (9-11 vs. $12-15 \mu \mathrm{m})$. Rauiella scita is presently only known from eastern North America and can also be differentiated by the absence of secondary branches and more regular and dense branching pattern (Fig. 4G), although less regular than in R. fujisa$n a$, and with only few secondary branches. Its leaves are also much smaller than those of $R$. thuidioides $0.6-0.8 \mathrm{~mm}$ long (Allen, 2014). The papillae on leaf lamina of $R$. scita are more similar to those of $R$. thuidioides; cells are described by Allen (2014) as densely pluripapillose on dorsal surface, bulging or unipapillose on ventral surface (cf. Fig. 3S). Rauiella scita has shorter setae, $0.8-1.4 \mathrm{~mm}$ vs. $1.8-2.2 \mathrm{~mm}$ long), and its spore size is similar to $R$. thuidioides $(8-12 \mu \mathrm{m})$. Rauiella thuidioides possibly most resembles members of the genus Haplocladium at casual observation with respect to similar, irregular and sparse branching pattern. In particular, stem leaves of $R$. thuidioides are strikingly similar in shape, size and strong plication to plants named Haplocladium microphyllum in northeastern Asia, although such plants differ from typical Central American plants representing the type of H. microphyllum. Species of Haplocladium can, however, be differentiated by the unipapillose cells, dioicous gametangia distribution 

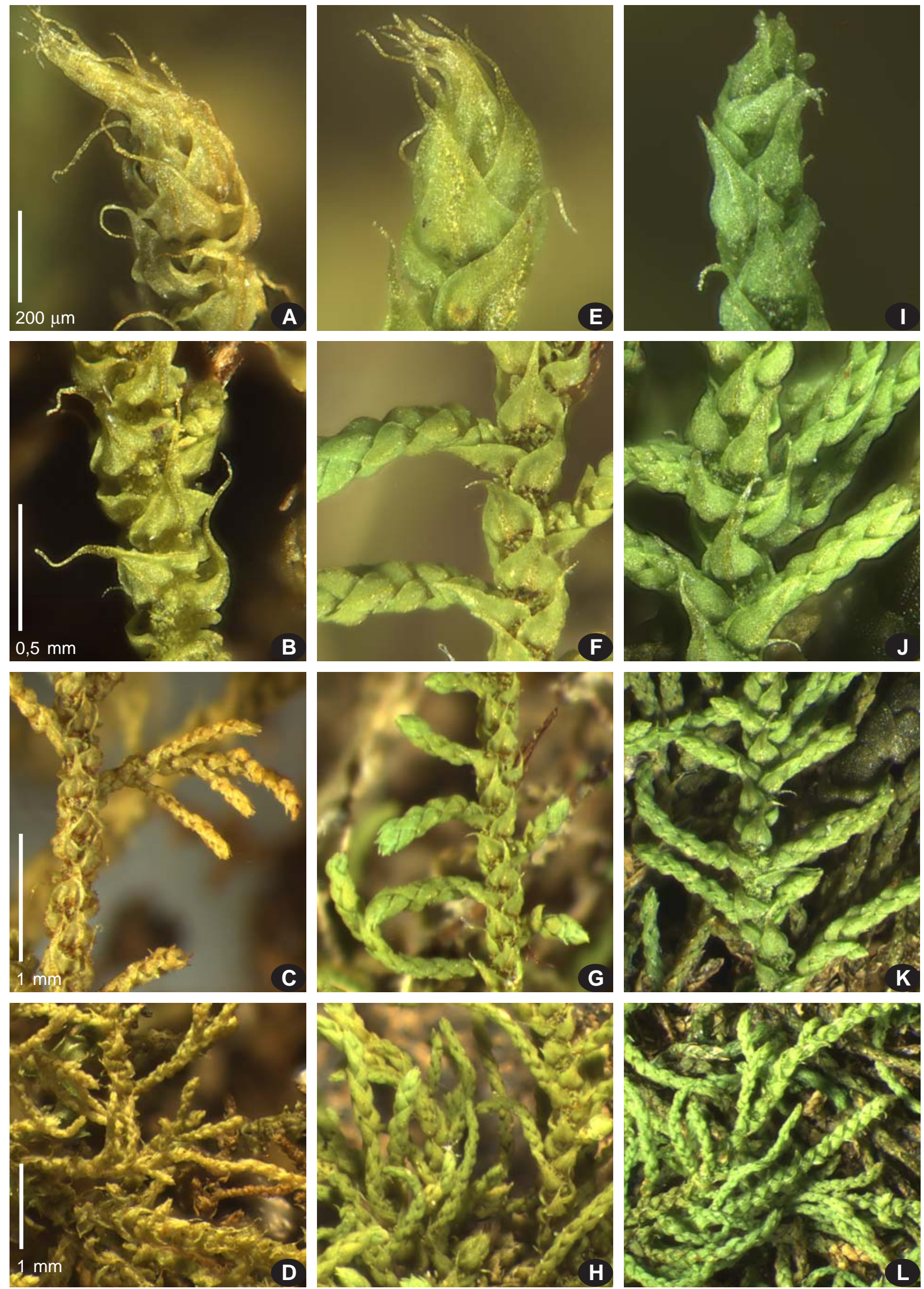

Fig. 4. Habits of R. thuidioides, from holotype (A-D), R. scita (from: USA, Maine, Allen 28294 MHA9057089; E-H), R. fujisana (from: Russia, Primorsky, Ignatov \& Ignatova 13-1380, MHA9048227; I-L). Each row at the same magnification. 
and mostly sparser paraphyllia, particularly on branches, and secondary branches are also absent. Boulaya mittenii is also unipinnate, more densely and regularly branched plant with thicker primary branches, cells are weakly unipapillose and somewhat collenchymatous, the plants are also dioicous. Thuidium species are dioicous as well and mostly are more densely and regularly bi- to tripinnate, except for, e.g., T. alleniorum, which however has only shortly pointed stem leaves and the branch leaves are incurved.

Ecology and Geography. Rauiella thuidioides was collected from half-shaded siliceous boulders in broadleaved alluvial wood surrounding the brook at 200-250 $\mathrm{m}$ a.s.l. It is not known how typical this habitat is for the species; the co-occurring $R$. fujisana is mostly found epiphytically in the same environments, but occasionally is also encountered on stones or bare ground. On the other hand, the habitat of shaded siliceous boulders in humid environment is also typical for the co-occurring species of the genus Haplocladium (currently referred to H. angustifolium, $H$. microphyllum and $H$. strictulum). The valley beneath Benevskie waterfalls has been well studied for bryophytes and contains many rare mosses of the Eastern element, including Arrhenopterum heterostichum Hedw., Boulaya mittenii (Broth.) Cardot, Forsstroemia konoi (Broth.) Enroth, Fedosov \& Ignatov, Hypopterygium flavolimbatum Müll. Hal., Orthotrichum consobrinum Cardot, Pylaisia coreana Nog., Rhizomnium striatulum (Mitt.) T.J. Kop. and many others. This discovery confirms that the bryoflora of the north-eastern Asia still contains unnoticed species, which might, however, prove more broadly distributed after previously unassigned material is revised. The use of molecular tools greatly enhances such efforts.

\section{ACKNOWLEDGEMENTS}

Jan Kučera acknowledges the loan of material from the herbarium DUKE arranged by B. Aguero and the effective laboratory work by Dr. Alžběta Manukjanová (University of South Bohemia, České Budějovice). The work of MI, EI, AF, OI and VF was supported by RSF project 18-14-00121. The work of VF was also supported by contract AAAAA20-120031990012-4 of the Botanical Garden-Institute FEB RAS. The work of AF was also supported by Tsitsin Main Botanical Garden state assignment no. 19-119012390082-6 and of EI by Lomonosov Moscow State University state assignment no. 121032500090-7. We also thank the Ministry of Higher Education and Science of the Russian Federation for support and the Center of Collective Use "Herbarium MBG RAS", grant 075-152021-678. Computational resources ('Metacentrum VO') were supplied by the Ministry of Education, Youth and Sports of the Czech Republic under the Projects CESNET (Project No. LM2015042) and CERIT-Scientific Cloud (Project No. LM2015085) provided within the program Projects of Large Research, Development and Innovations Infrastructures.

\section{LITERATURE CITED}

ALLEN, B.H. 2014. Maine mosses: Drummondiaceae - Polytrichaceae. Memoirs of The New York Botanical Garden 111: $i-x v i, 1-607$.

ALLEN, B.H. 2018. Moss flora of Central America. Part 4. Fabroniaceae-Polytrichaceae. - Monographs in Systematic Botany from the Missouri Botanical Garden 132: $i-x, 1-830$.

AUSTIN, C.F. 1880. Bryological notes. - Bulletin of the Torrey Botanical Club 7: 15-16.

BROTHERUS, V.F. (1925) Musci (Laubmoose) 2. Hälfte. Die natürlichen Pflanzenfamilien, Zweite Auflage. - Duncker \& Humblot, Berlin, $542 \mathrm{pp}$.

BUCK, W.R. 1991. The Generic Placement of Anomodon lagoensis. The Bryologist 94: 82. https://doi.org/10.2307/3243728

BUCK, W.R. 2014. Rauiella. - In: FNA Editorial Committee (eds.). Flora of North America, pp. 378-380.

BUCK, W.R. \& H.A. CRUM. 1990. An evaluation of familial limits among the genera traditionally aligned with the Thuidiaceae and Leskeaceae. Contributions from the University of Michigan Herbarium 17: 55-69.

CAI, Q.-Y., B.-C. GUAN, G. GE, \& Y.-M. FANG. 2019. Molecular Phylogeny of Chinese Thuidiaceae with emphasis on Thuidium and Pelekium. - arXiv:1902.06032 [q-bio].

DESHMUKH, U.B. 2021. Ignatovia, a new replacement name for Lazarenkoa Ignatov \& Ignatova (Leskeaceae, Bryophyta). - Phytotaxa 497 : 173-174. https://doi.org/10.11646/phytotaxa.497.2.11

GARCÍA-ÁVILA, D., E. DE LUNA \& A.E. NEWTON. 2009. Phylogenetic relationships of the Thuidiaceae and the non-monophyly of the Thuidiaceae and the Leskeaceae based on $r b c \mathrm{~L}$, rps 4 and the $r p s 4$ trnS intergenic spacer. - The Bryologist 112: 80-93. https://doi.org/ 10.1639/0007-2745-112.1.80

IGNATOV, M.S., O.D. DUGAROVA, A.V. FEDOROVA \& E.A. IGNATOVA. 2019. Lazarenkoa a new moss genus from the Russian Far East. Arctoa 28: 226-230. https://doi.org/10.15298/arctoa.28.21

IGNATOV, M.S., J. KUČERA, L. HEDENÄS, O.I. KUZNETSOVA \& E.A. IGNATOVA. 2020. A revision of the genus Orthothecium (Plagiotheciaceae, Bryophyta) in northern Eurasia. - Arctoa 29: 10-48. https://doi.org/10.15298/arctoa.29.02

KUČERA, J., O.I. KUZNETSOVA, A. MANUKJANOVÁ \& M.S. IGNATOV. 2019. A phylogenetic revision of the genus Hypnum: Towards completion. - Taxon 68: 628-660. https://doi.org/10.1002/tax.12095

NOGUCHI, A., Z. IWATSUKI \& T. YAMAGUCHI. 1991. Illustrated Moss Flora of Japan Vol. 4. - Hattori Botanical Laboratory, Nichinan, pp. 743-1012.

REIMERS, H.J.O. 1937. Die europäischen Haplocladium-Arten mit besonderer Berücksichtigung ihrer außereuropäischen Verbreitung und ihrer Verwandtschaft. - Hedwigia 76: 191-298.

RONQUIST, F., M. TESLENKO, P. VAN DER MARK, D.L. AYRES, A DARLING, S. HÖHNA, B. LARGET, L. LIU, M.A. SUCHARD \& J.P. HUELSENBECK. 2012. MrBayes 3.2: Efficient Bayesian Phylogenetic Inference and Model Choice Across a Large Model Space. - Systematic Biology 61: 539-542. https://doi.org/10.1093/sysbio/sys029

SOARES, A.E.R. 2015. A Família Thuidiaceae Schimp. no Brasil, um estudo taxonômico, filogenético e morfológico. - Universidade de Brasilia, $201 \mathrm{pp}$.

STAMATAKIS, A. 2014. RAxML version 8: a tool for phylogenetic analysis and post-analysis of large phylogenies. - Bioinformatics 30: 13121313. https://doi.org/10.1093/bioinformatics/btu033

TOUW, A. 2001. A review of the Thuidiaceae (Musci) and a realignment of taxa traditionally accommodated in Thuidium sensu amplo (Thuidium Schimp., Thuidiopsis (Broth.) M. Fleisch., and Pelekium Mitt.) including Aequatoriella gen. nov., and Indothuidium gen. nov. - Journal of the Hattori Botanical Laboratory 90: 167-209.

WIJK, R. \& W.D. MARGADANT. 1962. New combinations in mosses VII. - Taxon 11: 221-223. https://doi.org/10.2307/1216658

Received 1 December 2021 Accepted 20 December 2021 
Appendix. Specimen voucher information and GenBank accession numbers for newly generated sequences. Newly generated sequences are in bold.

\section{Taxon}

Cratoneuron filicinum Entodon concinnus

Entodon schleicheri

Rhytidium rugosum Pseudoleskeella catenulata Pylaisia polyantha Ptilium crista-castrensis Abietinella abietina Actinothuidium hookeri Boulaya mittenii Bryonoguchia molkenboeri

Echinophyllum sachalinense Echinophyllum sachalinense

Haplocladium angustifolium Haplocladium angustifolium Haplocladium microphyllum Haplocladium microphyllum Haplocladium virginianum Helodium blandowii Leskea polycarpa Pelekium pygmaeum Rauiella fujisana Rauiella fujisana

Rauiella fujisana

Rauiella scita

Raviella scita Raviella thuidioides Raviella thuidioides

\section{Thuidium alleniorum} Thuidium assimile Thuidium assimile Thuidium delicatulum Thuidium delicatulum Thuidium kanedae Thuidium kanedae

Thuidium pristocalyx Thuidium tamariscinum Thuidium tamariscinum Thuidium thermophilum

Thuidium thermophilum
Provenance

Czech Rep.: Horní Maršov Bulgaria: Trigrad gorge Russia: Irkutskaya Prov., Slyudyanka Austria: Mt Waldhorn

Czech Rep.: Kř́ízlice

Czech Rep.: Mikulov

Czech Rep.: Zliv

Czech Rep.: Horní Albeřice

China: Yunnan

Russia: Primorsky, Elomovsky

Russia: Primorsky, Chandolaz

Russia: Primorsky, Tadusha Russia: Botchi Reserve

South Africa: Amatola Mts Russia: Primorsky, Elomovsky USA: Florida, Orlando Bolivia: Gran Chaco USA: NC, Lillington Austria: Wanzenau Czech Rep.: Řeznovice Russia: Primorsky, Dalnegorsk Russia: Primorsky, Pidan Mt Russia: Khabarovsk Territory, Badzhal Range

Russia: Shikotan Island

USA: Maine, Schoodie Bay Canada: Nova Scotia Russia: Primorsky, Elomovsky Russia: Primorsky, Elomovsky

USA: NC, Atkinson Czech Rep.: Praha Russia: Primorsky, Chandalaz USA: NC, Duke Forest Norway: Luster Japan: Shikoku Island Russia: Shikotan Island

Russia: Primorsky, Elomovsky Czech Rep.: Vidov Russia: Iturup Island Russia: Kunashir Island Russia: Koryaksky Distr.
Voucher

Kučera 22385 (CBFS)

Kučera 14006 (CBFS)

Kučera 20340 (CBFS)

Kučera 12871 (CBFS)

Kučera 14759 (CBFS)

Kučera 19399 (CBFS)

Kučera 17064 (CBFS)

Kučera 22358 (CBFS)

Shevock 52072 (MW)

Kučera 21386 (CBFS)

Ignatov \& Ignatova

13-1936 (MW)

Ignatov et al. 13-1469 (MW) OK1174 KX396259 OL960671

MW9037836

Vanderpoorten 23 (DUKE)

Kučera 21282 (CBFS)

Majestyk 11418 (DUKE)

A. Fuentes s.n. (DUKE)

Aguero 19745 (DUKE)

Kučera 17242 (CBFS)

Kučera 19133 (CBFS)

Kučera 21867 (CBFS)

Kučera 21698 (CBFS)

MW9130131

Fedosov s.n. 15.VIII.2021 (MW)

Schofield 124652 (DUKE) R12287 OL990012 OL960688

Schofield 97336 (DUKE) R12369 - $\quad$ OL960689

Kučera 21386 (CBFS)

Ignatov et al. \#13-1264

(MHA)

B. Shaw 6015 (DUKE)

Kučera 22175 (CBFS)

Kučera 21386 (CBFS)

Aguero 19750 (DUKE)

MW9078688

MW9075555

Fedosov s.n. 27.VIII.21

(MW)

MW9066364

Kučera 22544 (CBFS)

MW9066363

Koroteeva 15-6/1-1

MHA9119722

Chernyagina \#5

MHA9119753 isolate ITS trnF-trnS

Cn2368 OL989999 -

En1020 MH613374 OL960672

En1507 MK327300 OL960673

Ry1522 MK327361 OL960693

Pk2099 OL990009 OL960682

Py1353 MH613484 OL960684

Pt1032 MH613481 OL960683

Ab2127 OL989996 OL960665

ThF22 OL989997 OL960666

Bo2126 OL989998 OL960667

ThF48 OL990000 OL960669

OL960670

Hc2288 OL990002 OL960675

Hc2130 OL990001 OL960674

Hc2289 OL990003 OL960676

Hc2334 OL990004 OL960677

Hc2293 OL990005 OL960678

He2108 OL990006 OL960679

Lk2097 OL990007 OL960680

Pe2129 OL990008 OL960681

R12125 OL990010 OL960685

ThF29 OL990011 OL960686

ThF77 -

OL960687

R12133 OL990014 OL960692

OK599 OL990013 OL960690

OL960691

Th2286 OL990015 OL960694

Th2100 OL990016 OL960695

Th2135 OL990017 OL960696

Th2278 OL990018 OL960697

ThF57 OL990019 OL960698

ThF54 OL825640 OL960700

ThF73 OL825641 OL960701

ThF55 OL990020 OL960699

Th2197 OL990021 OL960702

ThF56 OL990022 OL960703

OK3015 EF368013 OL960705
OK1176 KX396260 OL960668

OK3014 OL990023 OL960704 